\title{
Virulence of Campylobacter species: a molecular genetic approach
}

\author{
J. M. KETLEY
}

Department of Genetics, University of Leicester, University Road, Leicester LE1 7RH

\section{Introduction}

Campylobacter jejuni and related species have been known to be causative agents of human enterocolitis since the $1970 \mathrm{~s}^{1-3}$ Being the most common bacterial cause of diarrhoea in many industrialised countries, $C$. jejuni infection is responsible for a major public health and economic burden. ${ }^{4,5}$ Nevertheless, the level of public awareness is limited and after nearly two decades of scientific investigation, much of the biology of campylobacters and the mechanisms by which they cause disease are still relatively poorly understood. Indeed, since the association of Helicobacter pylori (previously classified as Campylobacter pylori) with gastritis and gastric ulcers, ${ }^{6.7}$ the scientific attention of many research groups was re-focused. More recently, scientific and governmental interest has been rekindled as the extent of the public health problem posed by Campylobacter spp. has become clear. ${ }^{4,5}$

The bacteria now recognised as members of the genus Campylobacter were first described at the beginning of this century. ${ }^{8}$ Probably the first campylobacters to be recognised were what are now known as $C$. fetus (formerly Vibrio fetus) which usually causes fetal and reproductive tract infection and abortion in animals. ${ }^{9}$ C. fetus infection of man is uncommon and usually occurs in immunocompromised patients. ${ }^{9-12}$ Campylobacters were considered to be almost exclusively veterinary pathogens $^{9,10}$ until the 1970 s when they were recognised in the stools of human patients with acute enterocolitis. ${ }^{1-3}$ Although their presence in the gut was suspected before this time,${ }^{13}$ the techniques traditionally used in clinical laboratories were not suitable for the isolation of campylobacters. Although $C$. jejuni and $C$. coli derived their names from an initial association with enteric disease in animals, ${ }^{14,15}$ they are the most important human pathogens in this genus, with the former usually responsible for the majority of enteric infections (80-90\%). However, various other species, including $C$. upsaliensis, $C$. hyointestinalis and $C$. lari also infect $\operatorname{man} ;^{9}$ the true

Received 12 Nov. 1994; accepted 17 Nov. 1994.

The 16th C. L. Oakley Lecture was given at the meeting of the Pathological Society of Great Britain and Ireland, at the Queen Elizabeth II Conference Centre, London, on 5 Jan. 1994. incidence of infection by these other species is unclear. ${ }^{4}$ As this research group's interests have been directed towards $C$. jejuni and $C$. coli, most background comments will necessarily be based on previous work on these two species.

\section{Campylobacter biology}

In physical terms, campylobacters are slim $(0.5-0.8 \mu \mathrm{m}$ long and $0.2-0.5 \mu \mathrm{m}$ wide), gram-negative rods which are spirally curved with tapering ends; it is from their shape that they derive their name, the Greek "campylo" meaning curved and "bacter" meaning rod. ${ }^{16}$ The cells usually possess a polar flagellum at one or both ends and this, presumably aided by the spiral cell morphology, imparts a high degree of motility to the cell. Most species are micro-aerophilic, requiring an $\mathrm{O}_{2}$ concentration of $3-15 \%$ and $\mathrm{CO}_{2}$ concentration of 3-5\%, but some are aerotolerant. ${ }^{16}$ Members of the genus will grow at a wide range of temperatures. $C$. jejuni and $C$. coli are thermophilic, growing best at $42^{\circ} \mathrm{C}$; this probably reflects adaptation to the temperatures found in their normal habitat, the intestine of warm-blooded animals and birds. C. fetus grows at $25^{\circ} \mathrm{C}$ and $37^{\circ} \mathrm{C}, \mathrm{C}$. cinaedi at $37^{\circ} \mathrm{C}$ but not $25^{\circ}$ or $42^{\circ} \mathrm{C}$ and $C$. cryoaerophila has a growth temperature optimum of $15^{\circ} \mathrm{C}$. Under certain environmental conditions, e.g., in stationary phase of growth or on exposure to atmospheric oxygen, campylobacters become round or coccoid in shape. This shape change has been associated with a transition from a viable culturable form to a viable but non-culturable state. ${ }^{17}$ It has been suggested that this transition is an adaptation to survival in adverse environments and there is a great deal of interest in this aspect of physiology and its role in transmission. There is evidence that campylobacters are infectious for neonatal mice in this form, ${ }^{18}$ but in a perhaps more relevant chicken model, the evidence is contradictory. ${ }^{19,20}$

\section{The genetics of Campylobacter spp.}

Campylobacter spp. have a small genome of $c$. $1600-1700 \mathrm{~kb}$ of very AT-rich DNA; the GC ratio is c. $30 \% .^{21-24}$ In comparison, the Escherichia coli genome is c. $4600 \mathrm{~kb}$ with a GC ratio of $50 \%$; thus, a 
campylobacter has a genome that is only $35 \%$ the size of that of $E$. coli. The small size of the genome is, perhaps, reflected in their requirement for complex media for growth and inability to ferment carbohydrates and degrade complex substances. ${ }^{16}$ Extrachromosomal elements in the form of both conjugative plasmids and bacteriophages have been reported in campylobacters. ${ }^{25}$

The number of genes reported to have been cloned from Campylobacter spp. is rather low in comparison to many other enteric pathogens. ${ }^{25}$ Most of these genes are "house keeping" genes usually involved in various biosynthetic pathways or they are ribosomal or transfer RNA genes. This situation is perhaps surprising considering that campylobacters are such important pathogens. It is generally accepted that campylobacter genes are often difficult to clone and subsequently analyse; this is thought to be due to several possible reasons. The high AT ratio may lead to instability because of the presence of promoter-like sequences and thus may lead to collapsing inserts. It is also thought that the use of complementation as a means of cloning campylobacter genes in the very different $E$. coli host strain can be problematic due to a lack of expression or required accessory factors, or both. Finally, the use of $E$. coli may also lead to problems due to different patterns of methylation or codon usage. There are now a few genetic tools available. ${ }^{25} \mathrm{~A}$ series of shuttle vectors has been constructed that contain both $E$. coli and campylobacter origins of replication as well as a campylobacter antibiotic resistance gene. Several plasmid-mediated drug resistance genes have been isolated that are proving to be a great technical help; these include tetracycline, kanamycin and chloramphenicol resistance genes. Interestingly, sequence evidence suggests that these genes have a gram-positive origin. ${ }^{25}$ Bacteriophage vectors appear to be useful for the construction of genomic DNA libraries and various options are available for genetic transformation. Campylobacters can be transformed by electroporation but with a low frequency $\left(c .1 \times 10^{3} / \mu \mathrm{g}\right.$ of DNA). ${ }^{26}$ Broad host range plasmids, such as IncP systems, will conjugate into Campylobacter spp. albeit at low frequency, but they are not maintained unless they contain a campylobacter plasmid origin of replication; thus, without this origin, a plasmid becomes a useful suicide vector.

Campylobacters are naturally transformable ${ }^{25,27}$ and preliminary evidence suggests that this requires a specific, but as yet unknown, sequence for uptake in a situation akin to that seen with naturally competent Haemophilus and Neisseria spp. In N. gonorrhoeae, pilin antigenic variation occurs by the uptake from lysed cells of silent pilin DNA sequences that recombine with expressed pilin genes in living, piliate cells. It has been speculated ${ }^{28}$ that, as many of the components of the SOS response system are not present, the control of the $\operatorname{rec} A$ gene in this organism may have evolved to provide transformation and recombination systems that facilitate evasion of host defence mechanisms. ${ }^{29}$ In $E$. coli, when DNA damage occurs, the protease activity of RecA results in cleavage of the LexA repressor of the $\operatorname{rec} A$ gene. However, specific amino-acid changes $(E$. coli amino acids Glu, ${ }^{159} \mathrm{Ala}^{180}$ and $\mathrm{Gln}^{171}$ ) found in $N$. gonorrhoeae, ${ }^{28}$ Bacteroides fragilis ${ }^{30}$ and Thiobacillus ferrooxidans $^{31}$ have been associated with elevated levels of protease activity in the absence of DNAdamaging agents ${ }^{32}$ that might effect the expression of LexA-responsive genes which are part of the SOS response. A fragment from the $C$. jejuni rec $A$ gene was cloned with a PCR-based approach (PCRDOP, see below). ${ }^{33}$ Sequence analysis of the 311-bp $C$. jejuni $\operatorname{rec} A$ fragment revealed its homology with $\operatorname{rec} A$ genes from other organisms. The $C$. jejuni DNA sequence showed $66.6 \%$ identity with the $\operatorname{rec} A$ sequence of Bacillus subtilis and $60.6 \%$ identity with that of $E$. coli. The deduced protein sequence also showed closer identity with $B$. subtilis RecA $(75 \%)$ than with $E$. coli RecA $(71 \cdot 1 \%)$. Interestingly, the deduced $C$. jejuni protein appears also to have substitutions at each of the relevant amino acid positions mentioned above. Soon after this observation, the complete sequence of the $C$. jejuni rec $A$ gene was reported ${ }^{34}$ and this allowed us to determine whether there is a consensus LexA binding site in the region upstream of the $C$. jejuni $\operatorname{rec} A$ open reading frame. As observed with $N$. gonorrhoeae, ${ }^{28}$ in addition to the amino acid changes mentioned above, the $C$. jejuni rec $A$ gene promoter region does not appear to contain a sequence with homology to the LexA binding region. Therefore, it is possible that in naturally transformable $C$. jejuni, the control of the $\operatorname{rec} A$ gene has evolved to increase the chance of recombining with exogenous DNA whilst avoiding the initiation of the SOS response. What relevance these observations have to campylobacter physiology and virulence remains to be determined.

The identification of important genes has been even more difficult due to the fact that transposons of either gram-negative or gram-positive origin have not been found to transpose in Campylobacter spp. As transposon mutagenesis has not yet been accomplished, we have attempted to construct a transposon designed to generate insertion mutants in C. jejuni. TnphoA permits the identification of genes encoding secreted proteins and thus increases the probability of isolating mutants in virulence determinant loci. ${ }^{35}$ We were unable to obtain mutants by use of this transposon in $C$. jejuni and determined that this was due to problems with expression of TnphoAencoded genes in this background. The aph- $A 3$ gene (kanamycin resistance) of $\operatorname{Tn} p h o A$ was replaced with an equivalent gene isolated from a $C$. coli plasmid $^{36}$ (TnCphoA). The resistance profile of transconjugants indicated that, unlike the $C$. coli-derived gene, aph- $A 3$ in TnphoA was not expressed in $C$. jejuni and a Western blot with anti-Tnp showed that the transposase (tnp) gene is also not expressed. A derivative of $\mathrm{TnCphoA}$ that contained a flanking tnp gene under the transcriptional and translational control of $C$. coli- 
derived chloramphenicol acetyl transferase (cat) gene promoter sequences (Pcat::tnp) was constructed. Invitro transcription/translation has shown that the Pcat::tnp gene construct is expressed in E. coli. The TnCphoA/Pcat::tnp system has now been conjugated into $C$. jejuni and Western blots indicated low level expression of Pcat::tnp. However, despite the use of two delivery strategies, we have been unable to detect transposition by TnCphoA/Pcat::tnp in C. jejuni. In designing this chimeric transposon every effort was made to optimise the level of tnp expression and the position of the Pcat::tnp gene with respect to TnCphoA. In addition, TnphoA mutagenesis of cloned campylobacter DNA in E. coli has proved to be very successful (Kiernan and Ketley, unpublished observation). Therefore, we can only speculate as to why the TnCphoA/Pcat: :tnp system did not work. It is possible that $C$. jejuni codon usage is not optimal for Tnp production, although this is unlikely to result in complete absence of tnp expression, and a low level of transposition might still be expected. Alternatively, the transposon sequences or Tnp, or both, may not be able to interact effectively with host factors that are also involved in the transposition event; this may be due to significant protein differences or even the complete absence of a particular host factor in Campylobacter spp.

\section{Clinical aspects}

The clinical consequence of infection by Campylobacter spp. in the majority of patients is a prodrome characterised by acute abdominal pain often with fever and general malaise which progresses to a profuse diarrhoea (reviewed in 37,38 ). Such prodromal symptoms are present in about half of infected patients. The incubation period before the appearance of symptoms usually ranges from 1 to 7 days, although the source of infection and, therefore, exact timing is often difficult to establish. The diarrhoeic stools often contain fresh blood, muco-pus and an inflammatory exudate with leucocytes; rapidly motile campylobacters may be seen in fresh faeces. Bacteraemia is rarely reported but is probably more common than suspected, especially in the early stages of infection; infrequent sampling and inappropriate culture conditions perhaps being the reason. The acute diarrhoea commonly lasts for 2-3 days with the patient becoming dehydrated and exhausted. Abdominal pain and discomfort persist during, and sometimes after, diarrhoea has stopped. Sigmoidoscopy usually reveals mucosal changes, ranging from oedema and hyperaemia with petechial haemorrhages to mucosal friability; these clinical observations may mimic those observed during acute ulcerative colitis. Inflammation of some areas of the ileum and jejunum with mesenteric adenitis is usually evident. Sometimes relapses occur but they are usually less severe than the first attack and patients may remain culture-positive for several weeks after the clinical symptoms have finished. Although campylobacter infection can result in a severe illness that may last more than a week, it is usually selflimiting and complications are uncommon. ${ }^{39}$ Perhaps the most notable complication is Guillain-Barre syndrome $^{40,41}$ which has a significant association with serological evidence of recent previous infection with Campylobacter spp. ${ }^{42-44}$

\section{Epidemiology}

It is clear that campylobacter enteritis is a major public health problem in industrialised countries. ${ }^{4,5}$ Since 1981, in England and Wales the number of laboratory reports of intestinal infection due to Campylobacter spp. has been greater than those due to other enteric pathogens, including the more newsworthy salmonellae (fig. 1). ${ }^{4}$ The incidence is also clearly rising and this probably reflects both a change in eating patterns, e.g., an increase in the popularity of chicken, and an increased awareness of campylobacter enteritis by the public health services. The peak isolation rate is in babies $<4$ months of age with a second major peak in young adults. However, when the rate of sampling is taken into account, the incidence in young adults is probably higher than in young children. ${ }^{45}$ Below the age of 45 years, there is an as yet unexplained but consistently higher incidence of infection in males than in females; after 45 years the rates become similar. The incidence of infection, as derived from laboratory isolations, is almost certainly a significant underestimate of the true rate of this disease in the general population. ${ }^{5}$ This situation reflects under-reporting due to the fact that not all physicians request stool cultures and not all diagnostic laboratories routinely screen for Campylobacter spp. A more accurate estimate was attempted in a limited study in a general practice population, ${ }^{46}$ the resultant annual incidence of $1.1 \%$ is close to an estimate of $1.0 \%$ made for the population in the USA. ${ }^{5}$ Although one has to be careful in suggesting that this small study is representative of a much larger population, relating this to the population of England and Wales would result in half a million cases/year. ${ }^{4}$ The extent of the problem is probably greater than even these figures suggest as the cases considered in the study were derived only from those reported to physicians; clearly, not all patients warrant or are willing to visit their physician. That these infections have an economic effect was demonstrated by a study ${ }^{47}$ in England in 1986 that estimated a cost of $£ 273 /$ case for health care and lost productivity. Combining a present day price estimate with an annual incidence of infection of $1.0 \%$ only serves to reinforce the economic burden of campylobacter infection.

The disease in developing countries appears to show a different picture to that in industrialised nations. ${ }^{48}$ Disease is usually restricted to children with no apparent peak in adults, no strong pattern of seasonality, a higher incidence of infection complicated by a higher rate of asymptomatic carriage, and a 


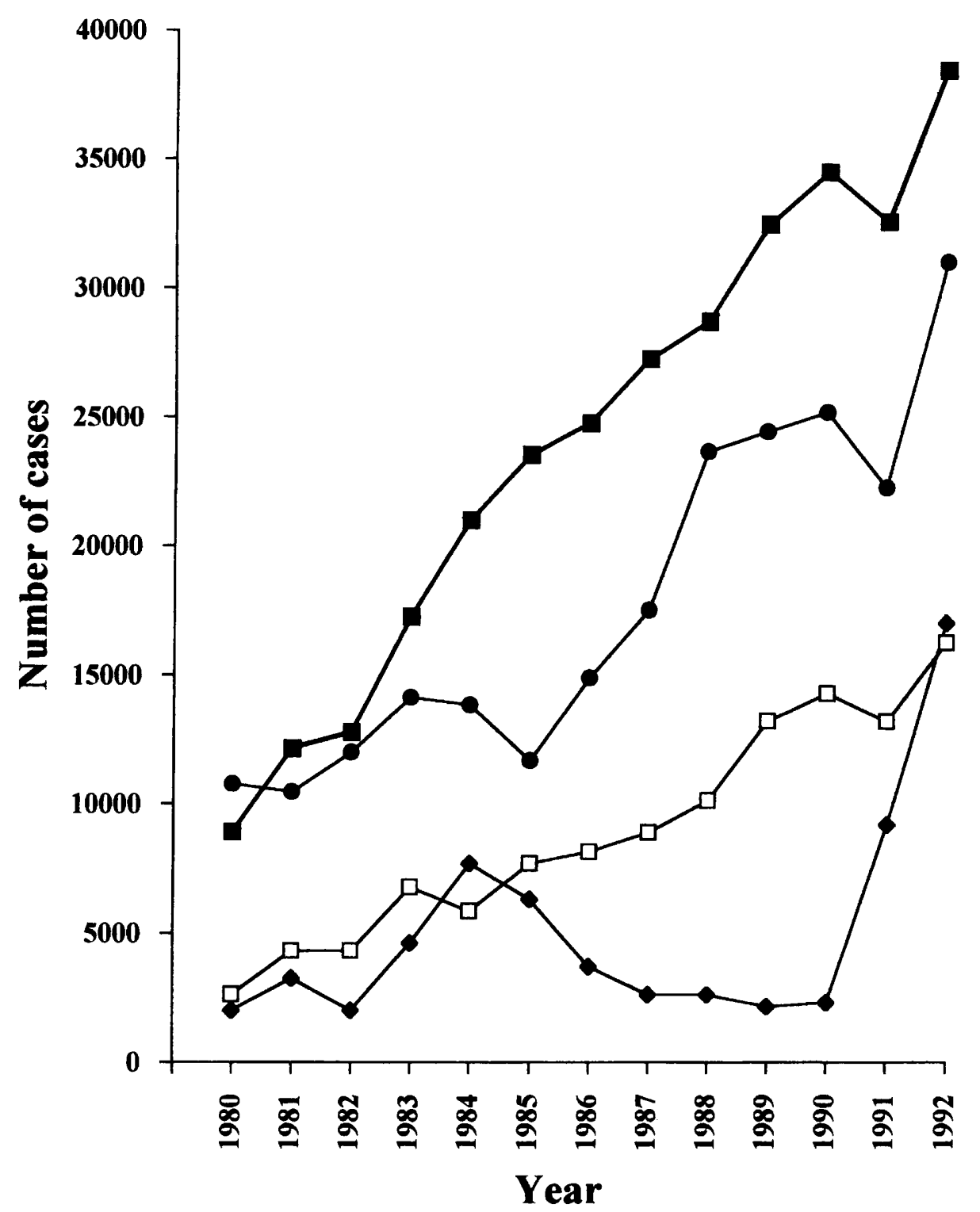

Fig. 1. Laboratory reports of gastrointestinal infections in England and Wales, 1980-1992: Campylobacter spp., Rotavirus, $\square$; Shigella sonnei, $\bullet$. Adapted from fig. 4.2 in ref. 4.

larger proportion of infections result in milder disease with a watery, non-inflammatory diarrhoea. This different epidemiological and clinical pattern of disease is probably due to a much higher exposure and infection rate early in life resulting in a different pattern of immunity. Although strain differences have been correlated with clinical symptoms (see below and 49-52), there is little evidence ${ }^{48}$ for the presence of different strains in developing countries to those found in industrialised countries. The importance of $C$. jejuni as a cause of travellers' diarrhoea ${ }^{48}$ has led to the observation that the spectrum of illness in travellers is similar to that described domestically.

\section{Transmission}

Campylobacter enteritis is considered to be a foodborne disease rather than food poisoning, infection often being derived from a range of foods and also water-based environmental sources (reviewed in 4, 16, $53,54)$. Although the identification of the origin of a particular infection is rarely made, the most common source in developed countries is thought to be domestic birds. Campylobacter spp. are part of the natural intestinal flora of a wide range of domestic and wild birds and animals. They are probably transmitted via the surface of meat as a result of faecal contamination during slaughtering. Consequently, infection results from undercooking meat and cross-contamination of uncooked foods. Other sources include untreated water, untreated milk, and sewage contamination; contact with pets, particularly with puppies with diarrhoea, is also a probable source. Most cases appear to be sporadic with outbreaks rarely identified and averaging about 10 /year in the UK. However, given the level of under-reporting, it is also possible that some sporadic cases reflect larger, unrecognised outbreaks. Perhaps the most unusual possible outbreaks have been associated with doorstep contamination of milk by magpies and jackdaws. ${ }^{\text {in }}$ The consistent seasonality of campylobacter infection, and the nature of the probable sources of infection, suggest that in 
industrialised countries various summer activities, e.g., barbeques, may be an important risk factor. Robinson's own experience ${ }^{56}$ and volunteer studies at the Center for Vaccine Development ${ }^{57}$ have shown that the infective dose that results in symptoms can be as low as $500-800$ organisms. Although neither the incubation period nor severity seemed to be affected by dose, the attack rate did correlate with increasing dose.

\section{Pathogenesis}

In the time since the association of Campylobacter spp. with human enteric disease, a reasonable understanding of the general clinical, microbiological and epidemiological aspects of infection has been achieved. However, the molecular mechanisms by which campylobacters cause disease are still rather poorly understood. It is now well accepted that the factors or virulence determinants required to cause disease are multi-factorial in nature; certainly campylobacters will be no exception to this. Campylobacters are foodborne pathogens, and, therefore, factors involved in survival and resistance to physiological stresses encountered in food and water are important for successful transmission and infection; the possibility that campylobacters can enter a viable, non-culturable state may thus be of great significance. On entry into the host, campylobacters must be able to adhere, multiply and colonise, and resist host defence mechanisms. In colonising the intestine campylobacters cause pathological changes that result in the clinical symptoms observed in patients, notably, diarrhoea. The virulence determinants involved in these events are generally not well characterised and some are rather controversial.

In association with food or water, campylobacters enter the host intestine via the stomach, surviving the acid barrier, and colonise the distal ileum and colon. This step requires the production of the flagellum which is the best characterised virulence determinant of Campylobacter spp. Early studies with genetically undefined mutants indicated that the flagellum was needed for adhesion and for colonisation in a range of animals. ${ }^{58-62}$ The unsheathed flagellum contains some of the Lior serotype-specific antigens ${ }^{63}$ and is phase ${ }^{60}$ and antigenically ${ }^{64}$ variable. The flagellin gene has been cloned and extensively characterised mainly by two groups, one in North America (C. coli) and one in Utrecht $(C$. jejuni) (reviews 65, 66). The gene has been mapped to the chromosome and, in the majority of isolates, is present in a direct tandem repeat. The two genes, $f l a A$ and $f l a B$, are of equal size $(c .1 .7 \mathrm{~kb})$ and in $C$. jejuni encode proteins with predicted mol. wts of 59538 and 59909 respectively; $f l a A$ and $f l a B$ are highly homologous $(>93 \%)$ with most heterogeneity being found in the $5^{\prime}$ and $3^{\prime}$ regions and in a small central region of the gene. A comparison of the $C$. coli and $C$. jejuni flaA gene products reveals an overall similarity of $87 \%$ with most variability being found in the central regions. In addition, FlaA flagellin shows a high degree of conservation with other bacterial flagellins, including those from Salmonella typhimurium and $B$. subtilis. The flaA and $f a B$ genes are transcribed independently and are regulated by different types of promoter ( $f l a A$ by a $\sigma^{28}$ and $f l a B$ by a $\sigma^{54}$ promoter; see below). Under the conditions tried so far, $f l a A$ is expressed at higher levels than $f a B$. Defined mutagenesis of each gene has shown that in the absence of FlaA, flaB encodes a flagellin protein that forms a short, truncated flagellum which confers poor motility. However, a role in normal flagellar function is supported by the observation that FlaB is incorporated into the whole filament (albeit in small amounts) and that although a $\mathrm{flaA}^{+}, \mathrm{flaB}^{-}$mutant produces a normal length flagellum, it demonstrates slightly decreased motility with respect to wild type. A molecular genetic approach has also led to the first characterisation of a role in virulence for a particular campylobacter gene. Defined mutants have shown that $f l a A$ is not required for adhesion but is necessary for the invasion and transcytosis of cultured cells of intestinal epithelial origin. ${ }^{67,68}$ These mutants have also confirmed that the flagellum is essential for the colonisation of chicks. ${ }^{69,70}$ It has been speculated ${ }^{71,72}$ that due to the unusual ability of $C$. jejuni to remain highly motile in mucus, adhesion to host cells is not actually necessary as the bacterial cell is able to remain in the intestine by successfully colonising the mucous blanket overlying the epithelium.

$C$. jejuni and $C$. coli are certainly able to adhere to tissue culture cells without subsequent invasion ${ }^{49}$ and one would assume that adhesion to the epithelial cell surface is necessary for subsequent invasion of the cell (see below). As experiments with differentiated enterocyte-like cells have shown that the flagellum does not seem to play a role in adhesion, has any other potential candidate adhesin been identified? Although the production of fimbriae by campylobacters has not been observed, various outer-membrane proteins ${ }^{\mathbf{7 3 - 7 5}}$ and LPS $^{62}$ have been described that bind to eukaryotic cells; however, these have not been characterised. One protein, PEB1, has been shown to bind to cells and the gene encoding for this potential adhesin has been cloned. ${ }^{76}$ Interestingly, the predicted protein has homology to amino-acid transporter systems of other bacteria. It is not yet clear whether the cell binding of PEB1 is an artefact or the protein may have a dual function of both amino-acid transport and intestinal cell binding.

After colonisation of the mucous blanket and adhesion to intestinal cell surfaces, campylobacters perturb the normal absorptive capacity of the intestine by damaging epithelial cell function either by cell invasion or the production of toxin(s), or both. There is now a substantial body of evidence supporting a role for host cell invasion in campylobacter-mediated disease. Inflammation and occasional bacteraemia strongly suggest that cell invasion is an important pathogenic mechanism. Although evidence of epi- 
thelial cell invasion in vivo is sparse, host cell invasion has been observed in both experimentally infected infant macaque monkeys ${ }^{77}$ and in the colon of patients. ${ }^{78}$ Furthermore, $C$. jejuni readily invade primary swine intestinal cells ${ }^{79}$ and the ability to invade tissue culture cells is well established. ${ }^{49,73,80-82}$

We have used the human colonic carcinoma line, Caco-2, which differentiates to form polarised enterocyte-like microvilliated monolayers, to study adhesion and invasion by well defined clinical isolates of $C$. jejuni and $C$. coli. ${ }^{49}$ The $C$. jejuni/coli strains tested were from two clinical groups of patients classified as having either colitis or watery (noninflammatory) diarrhoea. All strains adhered to Caco2 cells, but there was a significant correlation between the inability to invade Caco-2 cells and isolation of the strain from patients with non-inflammatory disease. It is important to note that some strains classified as "non-inflammatory" were, nevertheless, able to invade Caco- 2 cells. These strains may have been isolated from patients with colitis in which inflammatory cells in the stool were missed or absent at the time of diagnosis. Alternatively, host factors such as an immune response critically influenced the progress of infection and pattern of symptoms in a situation akin to that postulated for patients in developing countries. Nevertheless, the isolation of non-invasive strains from patients with non-inflammatory diarrhoea suggests that the range of symptoms observed in patients may be partly a reflection of strain differences. In addition, a correlation between the ability to invade and colitis lends support to a role for invasion in campylobacter pathogenesis.

The primary aim of future work should be to develop a detailed understanding of the mechanisms of host cell invasion by Campylobacter spp. and confirm any role in the pathophysiology of disease. Although several groups have investigated the mechanisms by which campylobacters invade host cells, no consensus has yet been established. In order to invade campylobacters need to synthesise new proteins (Wilkinson, Ketley and Williams, unpublished observations), ${ }^{\mathbf{8 3}, 84}$ whereas de-novo host cell protein synthesis is not essential. However, as a small number of bacteria are still able to invade despite inhibition of protein synthesis, it would seem that there may be a subpopulation of bacteria that possess the factors necessary for successful invasion; this suggestion is supported by the fact that campylobacters start to invade host cells within a very short time period (Wilkinson, Ketley and Williams, unpublished results). Campylobacter de-novo synthesised proteins have been seen following co-cultivation with host cells and in host cell-associated (i.e., adherent and invaded) bacteria (Wilkinson, Ketley and Williams, unpublished results). ${ }^{84}$ Proteins of the same size (43 and $45 \mathrm{kDa}$ ) as some of those observed during association are specifically induced in rabbit ileum. ${ }^{85}$ Several groups have found that, as with other well characterised invasive pathogens, including Salmon- ella, Shigella and Listeria spp., C. jejuni enters host cells via a microfilament-dependent process ${ }^{81,82,86}$ and in-vivo observations have suggested that cell entry is associated with microfilament accumulation. ${ }^{77}$ In contrast, other studies ${ }^{83,87}$ (Wilkinson, Ketley and Williams, unpublished results) have found that microfilament inhibitors did not affect invasion. The involvement of a microtubule-dependent pathway is supported by studies with inhibitors such as colchicine, vinblastine and vincristine ${ }^{83}$ (Wilkinson, Ketley and Williams, unpublished results). Oelschlaeger et al. ${ }^{83}$ also noted that invasion was inhibited by antagonists of coated pit formation and suggested that $C$. jejuni may enter host cells via coated pit-associated receptors with the resultant endosome interacting with microtubules; such a pathway would be unusual for an invasive bacterium. However, a recent study by Russell and Blake ${ }^{87}$ has further complicated the field as they could find no evidence of the involvement of an endocytic pathway involving coated pits, could not demonstrate the involvement of microfilaments and did not observe a requirement of de-novo bacterial protein synthesis for invasion. After entering the host cell, campylobacters remain within membrane-bound vacuoles in the cytoplasm, although in vivo, free $C$. jejuni cells were observed within the cytoplasm and were associated with a cytopathic effect. ${ }^{77}$ The range of apparently conflicting data obtained from studies is frustrating as it is difficult to draw any definitive conclusions as to the mechanisms and pathways by which campylobacters invade host cells. The differences between these invasion studies may stem from the range of different host cell types, Campylobacter strains and experimental conditions that have been applied. The only bacterial determinant that has been shown to be involved consistently in the process of invasion is the flagellum ${ }^{67,68,87}$ (see above).

We and others ${ }^{49,67,88}$ have observed the ability of Campylobacter spp. to translocate across an epithelial cell barrier; such translocation was first observed in salmonellae. ${ }^{89,90}$ This behaviour is of great potential significance for the pathophysiology of campylobacter disease. Translocated bacteria can be observed below the cell monolayer less than $1 \mathrm{~h}$ after inoculation above the cells (Brás-Goldberg and Ketley, unpublished results) ${ }^{88}$ and continue to translocate for at least $6 \mathrm{~h}$. The ability to cross the cell monolayer may be due to transcytosis (i.e., translocation via a cytoplasmic pathway) with the exit to the basolateral surface following initial invasion of the cell. However, there is evidence that campylobacters may also be able to cross the monolayer via a paracellular route. Electronmicroscopic observations ${ }^{83,88}$ indicate that campylobacters pass between cells and $\mathrm{we}^{49}$ have identified four distinct and reproducible phenotypes among clinical strains: (a) non-invasion; (b) invasion; (c) invasion with transcytosis; and (d) transcytosis without invasion. The latter group of strains would be predicted to take a paracellular route between tight junctions. Paracellular translocation does not appear 
to result in a large scale loss of tight junction integrity as transmonolayer electrical resistance does not significantly change during translocation (BrásGoldberg and Ketley, unpublished results). In contrast with salmonellae, ${ }^{89,90}$ electrical resistance does not change during the early stages of campylobacter invasion of host cells (Brás-Goldberg and Ketley, unpublished results). ${ }^{88}$ Campylobacters may, therefore, cross the intestinal epithelium by translocation or epithelial cell invasion followed by eventual cell lysis. An additional pathway would be via $\mathrm{M}$ cells and such a route has been proposed for shigellae. ${ }^{91,92}$ Interaction and translocation of the $M$ cells by campylobacters has been observed in rabbits, ${ }^{93,94}$ but not in Macaque monkeýs. ${ }^{77}$ For this route to be of pathological significance with entry into sub-epithelial tissues, campylobacters must resist killing by macrophages after passage through $\mathbf{M}$ cells and entry into underlying lymphoid tissue. Of significance, therefore, is one report ${ }^{95}$ that campylobacters can resist killing by macrophages. This observation is perhaps supported by the observation that campylobacters appear to be sensitive to the bactericidal action of serum ${ }^{96,97}$ and, therefore, bacteraemia ${ }^{96}$ may be a consequence of campylobacters circulating within leucocytes.

During colonisation, invasion and also in its freeliving state, $C$. jejuni is subjected to a range of stress conditions including changes in temperature, oxidation state, $\mathrm{pH}$ and osmolarity. In response to stress, bacteria upregulate specific groups of proteins that maintain the integrity of the cell. Recent evidence suggests that the HtrA (high temperature requirement) family of stress-response proteins may also be important in bacterial pathogenicity.$^{98}$ Curiously, HtrA production in different bacteria appears to be induced by distinct environmental stress conditions. For example, in $E$. coli the $h \operatorname{tr} A$ gene is essential for bacterial survival at high temperatures, ${ }^{99}$ whereas a $S$. typhimurium htrA mutant was temperature insensitive. ${ }^{98}$ Further in-vitro characterisation of this mutant revealed that it was more susceptible to oxidative stress than the parent, suggesting that it may be less able to withstand oxidative killing within macrophages. ${ }^{98}$ More recently, HtrA homologues have been identified as immunoreactive antigens in Brucella abortus and $H$. pylori. ${ }^{100,101}$ We applied the novel approach of utilising the polymerase chain reaction with degenerate oligonucleotide primers (PCRDOP) ${ }^{102}$ and inverse PCR mutagenesis $(\text { IPCRM })^{103}$ to construct a mutation in a $C$. jejuni htr $A$ gene homologue and inserted this mutation into the $h$ tr $A$-like locus of the $C$. jejuni genome by homologous recombination. The mutant is currently being tested in various phenotypic and virulence assays. Initial data suggest that although the ability to colonise chickens is not significantly decreased (Newell, Wren and Ketley, unpublished results), the $h \operatorname{tr} A$ mutant is not as invasive as the parent strain.

Infection by Campylobacter spp. leads to an enterocolitis involving intestinal tissue damage and bacteraemia. Furthermore, campylobacters are able to invade host cells and enter submucosal intestinal tissue and they also have homologues of genes associated with intracellular survival. Thus, host cell invasion and tissue destruction are likely to be key elements in pathogenesis. It could be postulated that the loss of enterocytes responsible for net fluid absorption and the eventual perturbation of epithelial integrity with resultant leakage of serosal fluid might lead to frank diarrhoea. However, invasion-related disruption of the epithelial layer may not be the only mechanism that results in net fluid loss. As noted above, one of the characteristic pathological changes associated with clinical disease is intestinal inflammation; this has also been observed in many animal models. ${ }^{77,93,104,105}$ In our work with the rabbit ileal loop model, ${ }^{96}$ we have described the elevation of cAMP, prostaglandin $\mathrm{E}_{2}\left(\mathrm{PGE}_{2}\right)$ and leukotriene $\mathrm{B}_{4}$ $\left(\mathrm{LTB}_{4}\right)$ levels in infected intestinal tissues and loop fluids. ${ }^{106}$ The loop fluids were found to cause elevated cellular cAMP levels in cultured Caco- 2 cell monolayers, an effect that could be inhibited by anti-PGE ${ }_{2}$ but not by anti-cholera toxin. These results suggest that there might also be an element of active intestinal fluid secretion in campylobacter diarrhoea that results from acute intestinal inflammation following tissue invasion.

Although tissue invasion and inflammatory changes could be solely responsible for the clinical picture resulting from campylobacter infection, toxins may also contribute to the disease process. The production of toxins is another confusing area of pathogenesis. Campylobacters have been reported to produce various toxic activities including a cholera-like toxin (CJT) and several cytotoxins, including a cytolethal distending toxin (CLDT), a shiga-like toxin (SLT) and a haemolysin. Much of the earlier work concerning these toxins has been reviewed previously. ${ }^{10,16,38,52,107}$

The putative cell-associated SLT ${ }^{108}$ was found to be produced in very low levels equivalent, in fact, to that found in enterotoxigenic $E$. coli, Vibrio cholerae, $E$. coli $\mathrm{K} 12$ and normal intestinal flora $E$. coli strains. There was no correlation between production and the clinical background of the strain and no SLT gene sequences were found. With respect to other cytotoxic activities (examples are 109-118), there have been many reports, but there are sometimes little detailed or consistent data on the putative toxin activity. Consequently, a comprehensive and conclusive description of a campylobacter cytotoxin has yet to emerge. It is not clear whether there are several or only one cytotoxic moiety and certainly the gene(s) that might encode the cytotoxin(s) have not yet been identified. Nevertheless, the clinical presentation, which often involves intestinal tissue damage and an associated inflammatory response, is not inconsistent with the action of cytotoxins.

The evidence for a role and even the production of the campylobacter enterotoxin is not convincing. Several groups ${ }^{50,51,119-127}$ have described a toxin that 
elongates $\mathrm{CHO}$ cells like cholera toxin, is detected with a GM1-based ELISA, and produces fluid accumulation in intestinal loops. They report the partial purification of CJT and the production of specific antisera. Furthermore, the production of CJT was reported to correlate with the watery diarrhoea observed in developing countries. There are even reports that, under low stringency hybridisation conditions, the $C$. jejuni chromosome contains nucleotide sequence similarities with cholera toxin and heat-labile toxin. ${ }^{128,129}$ In contrast, several other independent groups, even with similar strains, cannot demonstrate the production of CJT, find no antibody response against it and cannot demonstrate any DNA sequence similarity. ${ }^{52,107,130-132}$ It is not yet clear whether CJT is an artefact arising from non-toxin proteins containing similar epitopes or if the strains in which it is expressed and the conditions of expression are restricted. As with other bacterial pathogens, it is possible that the nature of toxin production by Campylobacter spp. is complex and involves a range of different toxins expressed under various, as yet, unknown conditions.

Lipopolysaccharide (LPS) is a virulence determinant in many species of gram-negative bacteria. It has been shown to contribute to several aspects of the pathogenic process, including serum resistance, resistance to phagocytic killing and cell toxicity. Sialylation of LPS has been shown to play a role in virulence in some pathogens (e.g., Neisseria and Haemophilus spp. ${ }^{133,134}$ ) by enhancing serum resistance. Much progress has been made on the biochemical characterisation of $C$. jejuni LPS $^{135-142}$ and most attention has been directed towards the utilisation of LPS in serotyping. $C$. jejuni LPS can either consist of a low mol. wt fraction which is similar to the characteristic LPS found in Neisseria and Haemophilus spp. or, in addition, it may also contain a high mol. wt fraction. ${ }^{135}$ The genetic basis for the production and variation in $C$. jejuni LPS is at present completely unknown. The role of LPS in the virulence of other gram-negative pathogens gives an intellectual basis for the search for such role in $C$. jejuni. A single report ${ }^{62}$ details the role of both LPS and flagellin as important adhesins. Although the role of the flagella in colonisation and invasion has now been confirmed with defined genetic mutants, similar studies have yet to be done on LPS. Although LPS serotypes prevalent in human disease have been shown to bind sialic acid, ${ }^{135}$ the role of endogenous or exogenous sialylation in virulence is again unknown.

\section{The genetic regulation of campylobacter virulence}

Bacterial pathogens are highly adapted microorganisms that express a complex and multifactorial virulence phenotype. Given the number of genes probably involved in the virulence phenotype and the possibility that the pattern of expression may need to be modulated during the infective process, pathogenic bacteria require effective signal transduction systems with mechanisms to tightly and co-ordinately regulate virulence determinant expression. These systems regulate the production of specific virulence factors in response to differing host-specific conditions encountered throughout infection; such signals include temperature, $\mathrm{pH}$, osmolarity and iron. ${ }^{143}$ The involvement of multiple regulatory systems raises the possibility of the existence of a global network of interacting regulatory cascades. Therefore, cross-regulation between pathways may be used by pathogens to further direct and fine tune virulence determinant gene expression. It is highly likely that Campylobacter spp. also utilise similar, perhaps interacting, regulatory systems to adapt and survive within the host. Such systems would be essential for campylobacters to transfer successfully from a low nutrient environment to a host intestinal tract. They are also likely to play a role in any change of gene expression required for the progression from a commensal state in a bird to survival during cell and tissue invasion in man. Consequently, we and others have used a range of strategies to identify potentially important regulatory systems in Campylobacter spp.

Iron is an essential element for all living organisms and pathogenic bacteria must obtain iron throughout the infective process. The restriction of free iron by mammalian hosts is a non-specific defence mechanism and, consequently, bacterial pathogens have evolved systems to obtain free iron during infection. These systems are expressed maximally under iron-restricted conditions with negative regulation being controlled by the fur locus (Ferric uptake regulator). ${ }^{144}$ Genes encoding virulence determinants not directly involved in iron scavenging may also be regulated by iron. ${ }^{145-149}$ In E. coli, more than 30 genes are repressed by the Fur protein $^{144}$ which utilises ferrous iron as co-repressor and binds to specific operators. ${ }^{1{ }^{50}, 151}$ Highly conserved homologues of fur have been cloned from several pathogenic species, ${ }^{152-157}$ and iron regulated genes in some species are preceded by promoters containing sequences with similarity to Fur-responsive operators in E. coli. ${ }^{158,159} \mathrm{~A}$ less highly conserved fur homologue, $d t x R$, has been found in Corynebacterium diphtheriae. ${ }^{160}$

In common with other bacteria, $C$. jejuni synthesises new envelope-associated proteins in response to iron stress. ${ }^{161}$ One such protein is probably a component of a high affinity uptake pathway for haemin and haemoglobin, ${ }^{14}$ thus, an iron-responsive regulatory circuit similar to the Fur system probably regulates a subset of virulence-associated genes in $C$. jejuni. However, we were unable to detect a protein in $C$. jejuni extracts that cross reacted in Western blots with an antiserum raised against the purified $E$. coli Fur protein (fig. 2). To search for a protein with Fur-like activity, an intracellular probe was constructed consisting of the coding sequence of a cat gene of campylobacter origin just upstream of which a synthetic Fur-responsive operator sequence based on the E. coli Fur-binding consensus sequence was 


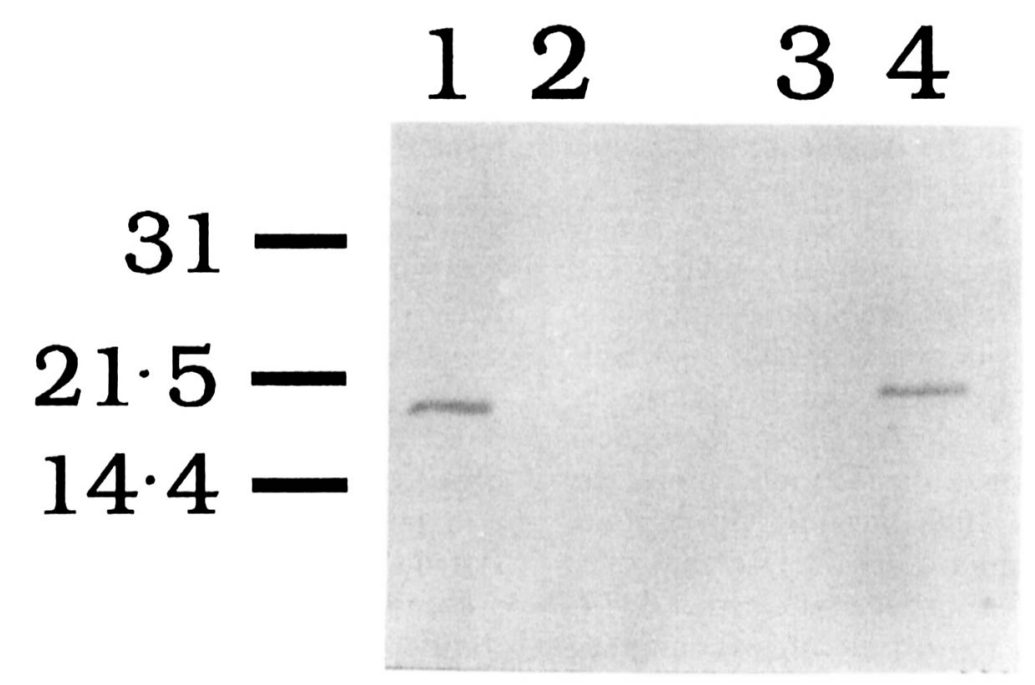

Fig. 2. Western blot analysis of whole cell bacterial extracts with polyclonal rabbit anti-Fur serum. Lane 1, E. coli JB1698 (fur $\left.{ }^{+}\right) ; 2, E$. coli H1780 (fur $)$; 3, C. jejuni 81116; 4, V. cholerae CVD103. Positions and sizes $(\mathrm{kDa})$ of mol. wt markers are indicated.

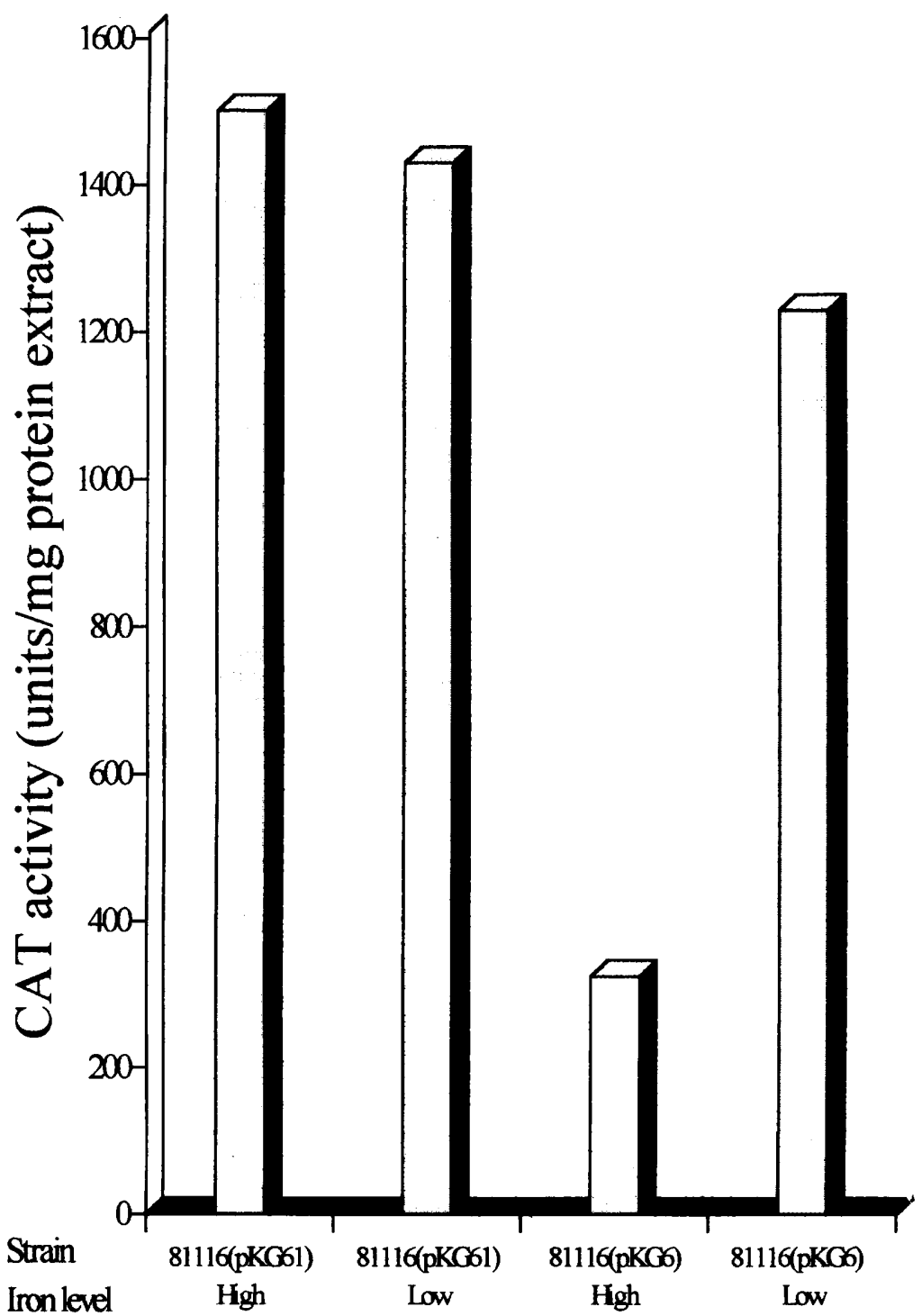

Fig. 3. Chloramphenicol acetyl transferase (CAT) activity in extracts of $C$. jejuni strains $81116(\mathrm{pKG}$ ) and $81116(\mathrm{pKG}$ G1) grown in high or low levels of iron (Mueller Hinton broth supplemented with either $60 \mu \mathrm{M} \mathrm{FeSO}_{4}$ or $25 \mathrm{~mm}$ deferrioxamine mesylate, respectively).

inserted. ${ }^{162} C$. jejuni clones containing this construct or a control plasmid lacking a Fur-binding operator were grown in either high-iron or iron-restricted media and assayed for CAT activity. While the level of CAT activity in extracts prepared from control plasmid transformants was not significantly affected by the 


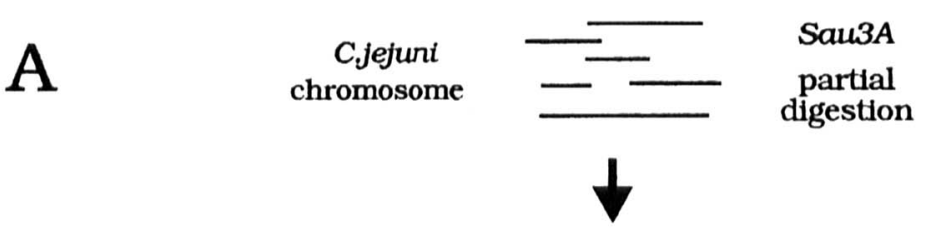

Stze select $1-10 \mathrm{kbp}$

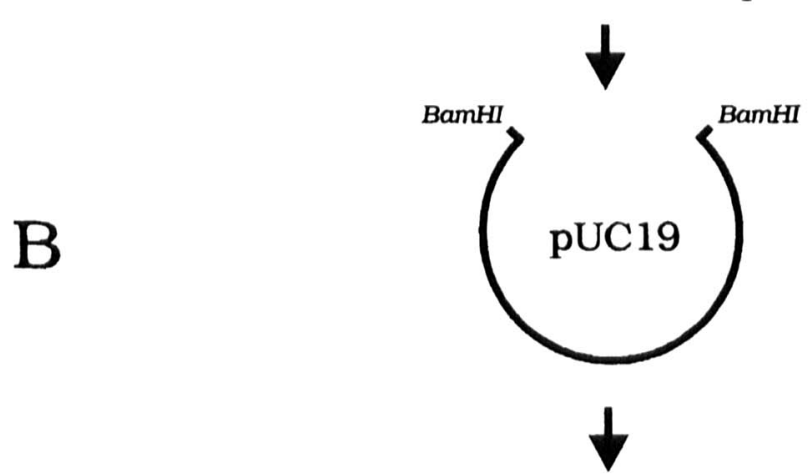

C

Transform into

E. coli $\mathrm{H} 1780$ (fur-)

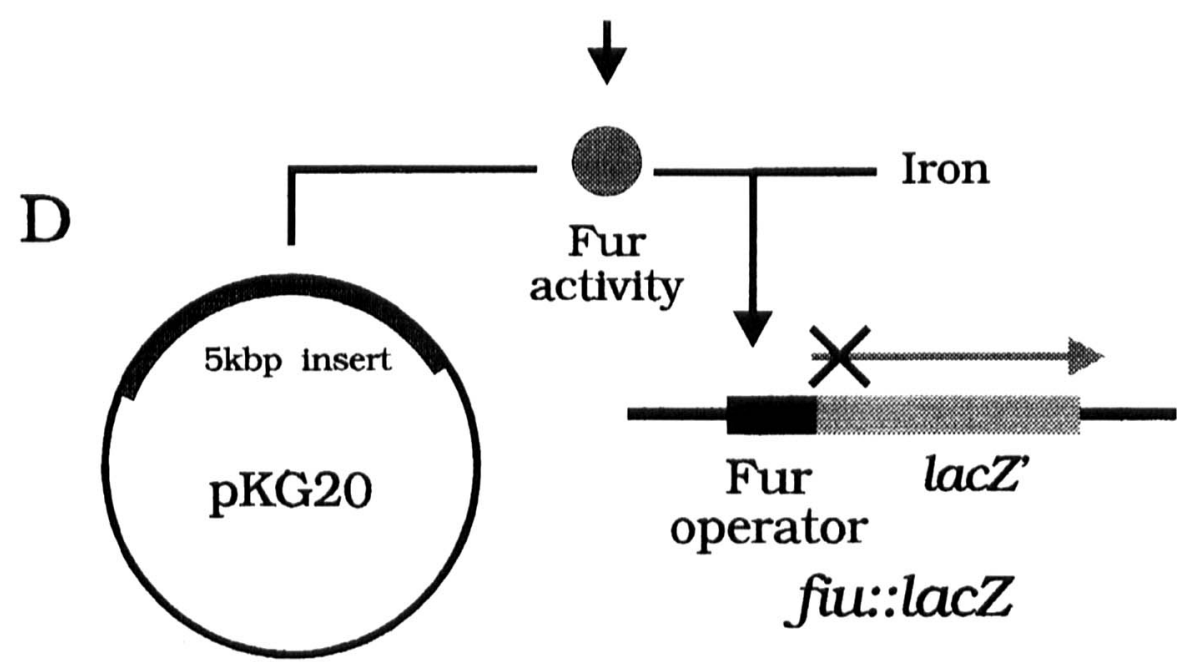

Fig. 4. Strategy used to clone the C. jejuni fur gene. A, C. jejuni strain 81116 chromosome is partially digested with Sau3A and 1-10-kb fragments are selected; B, genomic fragments are ligated into BamHI-restricted pUC19; C, the library is transformed into $E$. coli fur ${ }^{-}$strain $\mathrm{H} 1780$ and transformants are selected on $\beta$-galactosidase indicator plates with high levels of iron $\left(60 \mu \mathrm{M} \mathrm{FeSO} \mathrm{O}_{4}\right) ; \mathrm{D}$, a clone containing $5 \mathrm{~kb}$ of $C$. jejuni DNA (pKG20) expressed a Fur activity which, with iron, co-repressed the expression of the H1780 fiu::lac Z gene fusion.

iron status of the cells, extracts prepared from the fur operator plasmid transformants which had been grown in low-iron conditions consistently contained $c$. four-fold higher activity than those prepared from cells grown in high-iron medium (fig. 3). The gene homologue encoding this Fur-like protein was cloned by use of a strategy (fig. 4) that utilised an E. coli strain containing a fur mutation and a gene fusion between a Fur-repressible gene and $l a c Z$. Thus, even in high-iron conditions, there is no repression of the gene fusion, resulting in high levels of $\beta$-galactosidase expression. However, providing a functional fur gene in trans results in iron-dependent repression of the gene fusion and consequent reduction in $\beta$-galactosidase expression. A plasmid containing a $c$. 5-kb insert partially complemented the fur mutation in the indicator strain. The gene encoding the $C$. jejuni Fur activity was located by transposon mutagenesis and sequenced. ${ }^{162}$
The predicted mass of the putative $C$. jejuni Fur protein based on the deduced amino-acid sequence is $17990 \mathrm{Da}$. Analysis of the C. jejuni fur gene has identified two sequences with similarity to the $E$. coli Fur-binding consensus sequence ${ }^{150}$ overlapping putative -10 and -35 promoter sequences. This suggests that, like its counterpart in E. coli ${ }^{163}$ and $N$. gonorrhoeae, ${ }^{157}$ the $C$. jejuni fur is autoregulated. This observation is supported by experiments on the expression of a fur promoter fusion to a promoterless cat gene which showed a degree of repression by iron (Wooldridge and Ketley, unpublished results). The Fur homologues of other gram-negative bacteria are highly conserved. By contrast, the Fur-like protein of C. jejuni is relatively highly diverged; only the Fur homologue DtxR of the gram-positive Cor. diphtheriae is less like the other Fur proteins. All other known Fur proteins are at least $50 \%$ identical with respect to each 
other, whereas the $C$. jejuni Fur protein is $35 \%$ identical to its closest match (the Fur protein of Pseudomonas aeruginosa). The motif CXYCG, which is present within metal-binding centres of many proteins, has been suggested as a metal-binding motif within the Fur protein $;^{157,164}$ this motif was found within the $C$. jejuni Fur-like protein. The degree of dissimilarity of the $C$. jejuni Fur protein with respect to its $E$. coli counterpart is reflected both antigenically, by its lack of reactivity in Western blots, and functionally, by the low level of repression of an E. coli furregulated promoter compared to that afforded by the $E$. coli Fur protein. ${ }^{162}$ If $C$. jejuni Fur-like protein is truly the major iron-dependent regulator in this organism, its recognition sequence, as well as the repressor itself, may have diverged significantly between the two species. Since Fur and Fur-like repressors are known to regulate some virulence determinant genes in other bacteria, it is likely that the Fur-like repressor protein also regulates a subset of $C$. jejuni genes with a role in pathogenesis.

Many of the regulatory systems that have been identified can be grouped into families of bacterial transcriptual regulators. The superfamilies include the two-component regulatory systems, the LysR group of regulatory elements and the AraC group. ${ }^{165} \mathrm{Se}-$ quence analysis of the members of such families has revealed a large degree of sequence conservation within the same organism and between bacteria from different species. One group of regulatory signal transduction systems which are often involved in pathogenicity belong to a family of two-component transcriptional regulators that direct responses to external environmental stimuli. ${ }^{166-168}$ Members of this family that have been associated with virulence include phoP $/ Q$ in Salmonella spp, bvgS/A in Bordetella spp. and $\operatorname{vir} A / G$ in Agrobacterium spp. The two components often consist of sensor proteins and response regulator $(\mathrm{RR})$ proteins that interact to regulate the transcription of a number of genes co-ordinately. The sensor protein is a histidine protein kinase (HPK) often located in the cytoplasmic membrane and it monitors changes in specific environmental parameters. The sensory information is transferred to the cytoplasmic response regulator by phospho-transfer from the HPK to the RR. It is highly likely that Campylobacter spp. utilise HPK/RR systems to allow them to adapt and survive within the intestinal tract. It is also likely that they are important for survival in the environment. We have used the high degree of sequence conservation within this regulatory system to use the PCRDOP strategy to identify new genes encoding campylobacter response regulatory proteins. Three of the RR genes identified so far have greatest homology with $E$. coli che $Y, S$. typhimurium phoP and $S$. typhimurium ompR respectively. These genes are now being mutated to assess the role of the HPK/RR systems in campylobacter virulence and survival.

There is now some insight into the regulation of flagella production; $f a A$ and $f l a B$ are independently transcribed with $f l a A$ regulated by a $\sigma^{28}$ and $f l a B$ by a $\sigma^{54}$ promoter. Under the conditions assessed so far, $f l a A$ is expressed at much higher levels than $f a B$. Transcription from the $\sigma^{54}$ promoter has been found to be environmentally modulated by conditions such as temperature, $\mathrm{pH}$ and inorganic salt and divalent cation concentrations. ${ }^{169,170}$ Miller et al. ${ }^{170}$ have identified a gene $(f b A)$ that may play a role in the regulation of flagellin expression. Interestingly, $f b A$ shows homology with a group of proteins involved in the secretion of regulation of virulence-related proteins that includes Yersinia pestis $\mathrm{LcrD}$ and $S$. typhimurium InvA. A $C$. jejuni $f b A$ mutant did not produce functional flagella and flagellin protein was not present in the cytosol; these data suggest that FlbA (or a gene downstream) is regulating the expression of $f l a$. Flagella synthesis has been observed to undergo both phase and antigenic variation, ${ }^{60,64}$ the molecular basis of which is not clear. Flagellin is also posttranslationally modified, possibly by phosphorylation of certain serine residues. ${ }^{65,66}$

\section{Future molecular genetic strategies}

Further progress is urgently required in both our understanding of the molecular basis of campylobacter virulence and the nature of the bacterial interactions with the host during the progress of infection. As the work with the flagellin genes has demonstrated so elegantly, a molecular genetic approach is a powerful and rapid strategy to achieve this objective in Campylobacter spp. However, the molecular genetic methodologies currently available for the analysis of campylobacters are not as well developed as in other common pathogens. Although limited success has been achieved with some current commonly used molecular genetic approaches, the identification of novel genes that may encode complex virulence phenotypes (e.g., invasion) would be greatly facilitated by the development of efficient random insertional mutagenesis. As the currently available transposon systems have not been useful, either a campylobacterspecific transposon will have to be identified and developed or an alternative mutation strategy must be established. Although the PCR-based approach has proved to be rapid and circumvents the requirement for cloning and expressing genes or using transposon systems to identify specific genes of interest, it is restricted to the identification of genes for which sequence information has been obtained already from other bacteria.

Given the limitations encountered with many molecular genetic methodologies and the small size of the campylobacter chromosome, perhaps the most efficient and powerful future course would be the direct analysis of the campylobacter genome. Sequence analysis of the entire genome would revolutionise our understanding of the biology and particularly the genetics of this important food-borne pathogen. This strategy would certainly be facilitated by the small size 
of the $C$. jejuni chromosome, ${ }^{21-25}$ the existence of several physical maps of the chromosome derived by pulsed-field gel electrophoresis ${ }^{21-25}$ and the rapid development of genome analysis techniques by other projects. Given that the availability of bacterial DNA and protein sequence information will continue to rise at an exponential rate, homology searches of sequences is very likely to yield definitive information on C. jejuni genomic sequences. Such a genetic approach cannot be carried out in isolation as it would be useful in the long term only if combined with an investigation of the biological role and relevance of particular sequences of interest. With respect to virulence, although various cell assays are now well established, the use of in-vivo models will also be necessary to characterise precisely any putative pathophysiological mechanisms inferred from sequence analysis. Colleagues in the UK are discussing the organisation and support of a campylobacter genome project which, it is hoped, will attract support and collaboration from "campylobacterologists" throughout the world.

\section{Conclusions}

During the past decade it has become clear that Campylobacter spp. are significant causes of debilitating enteric disease in developed countries. Although these bacteria have remained obscure to the general public, the recent higher profile in the minds of

\section{References}

1. Skirrow MB. Campylobacter enteritis: a "new" disease. BMJ 1977; 2: 9-11.

2. Butzler JP, Dekeyser P, Detrain M, Dehaen F. Related vibrio in stools. J Pediatr 1973; 82: 493-495.

3. Dekeyser P, Gossuin-Detrain M, Butzler JP, Sternon J. Acute enteritis due to related vibrio: first positive stool cultures. $J$ Infect Dis 1972; 125: 390-392.

4. Advisory Committee on the Microbiological Safety of Food. Interim Report on Campylobacter. London: HMSO, 1993.

5. Tauxe RV. Epidemiology of Campylobacter jejuni infections in the United States and other industrialized nations. In: Nachamkin I, Blaser MJ, Tompkins LS (eds) Campylobacter jejuni: current status and future trends. Washington DC, American Society for Microbiology. 1992: 9-19.

6. Marshall BJ. Unidentified curved bacilli on gastric epithelium in chronic active gastritis. Lancet 1983 ; 1 : 1273-1275.

7. Marshall B. History of the discovery of C. pylori. In: Blaser MJ (ed) Campylobacter pylori in gastritis and peptic ulcer disease. New York, Igaku-Shoin. 1989: 7-23.

8. McFadyean F, Stockman S. Report of the departmental committee appointed by the board of agriculture and fisheries to enquire into epizootic abortion, vol 3. London, His Majesties Stationary Office. 1913.

9. Mishu B, Patton CM, Tauxe RV. Clinical and epidemiologic features of non-jejuni, non-coli Campylobacter species. In: Nachamkin I, Blaser MJ, Tompkins LS (eds) Campylobacter jejuni: current status and future trends. Washington DC, American Society for Microbiology. 1992: 31-41.

10. Cover TL, Blaser MJ. The pathobiology of Campylobacter infections in humans. Annu Rev Med 1989; 40: 269-285.

11. Guerrant RL, Lahita RG, Winn WC, Roberts RB. Campylobacteriosis in man: pathogenic mechanisms and review of 91 blood stream infections. Am J Med 1978; 65 : $584-592$. scientists and governments and the increased emphasis on health issues by the public will no doubt result in consumer education programmes that are likely to have a significant impact on the incidence of infection. Hopefully, it is apparent that after two decades of investigation we have many strong leads but few conclusive answers to how Campylobacter spp. cause disease in man. There is good evidence that motility and invasion play a role in pathogenesis but although campylobacters may produce several toxins, their role is far from clear. The very considerable advances in the understanding of the physiology and pathogenesis of campylobacter infection which will result from genetic approaches combined with relevant biological analysis will lead to new strategies for controlling and even eliminating campylobacters from food in the UK. This elimination would be expected to result in a commensurate reduction in the number of cases of bacterial gastro-enteritis in this country.

I gratefully acknowledge the Royal Society for my University Research Fellowship and the Wellcome Trust, Nuffield Foundation, Royal Society and BBSRC for their generous research support. I also thank members of my group who have contributed to this research including, K. Wooldridge (Wellcome Trust), Michele Kiernan (MRC Studentship), Ana Brás-Goldberg (JNICT Studentship), J. Henderson (BBSRC) and Anne Wood (Wellcome Trust). Many thanks to my collaborators, including P. Everest, B. Wren, H. Goossens and D. G. Newell and to the many undergraduates and MSc students who have contributed to both the work and the social life of the Group! Finally, I would particularly like to acknowledge Peter Williams' scientific collaboration, advice and friendship over the past few years.
12. Mandal BK, De Mol P, Butzler JP. Clinical aspects of Campylobacter infections in humans. In: Butzler J-P (ed) Campylobacter infection in man and animals. Boca Raton, Fla, CRC Press Inc. 1984: 21-31.

13. Levy AJ. A gastro-enteritis outbreak probably due to a bovine strain of vibrio. Yale J Biol Med 1946; 18: 243-258.

14. Jones FS, Orcutt M, Little RB. Vibrios (Vibrio jejuni, n. sp.) associated with intestinal disorders of cows and calves. $J$ Exp Med 1931; 53: 853-863.

15. Doyle LP. The etiology of swine dysentery. Am J Vet Res 1948; 9: $50-51$.

16. Griffiths PL, Park RWA. Campylobacters associated with human diarrhoeal disease. J Appl Bacteriol 1990; 69: 281-301.

17. Rollins DM, Colwell RR. Viable but non-culturable stage of Campylobacter jejuni and its role in the natural aquatic environment. Appl Environ Microbiol 1986; 52: 531-538.

18. Jones DM, Sutcliffe EM, Curry A. Recovery of viable but nonculturable Campylobacter jejuni. J Gen Microbiol 1991; 137: 2477-2482.

19. Stern NJ, Jones DM, Wesley IV, Rollins DM. Colonisation of chicks by non-culturable Campylobacter spp. Lett Appl Microbiol 1994; 18: 333-336.

20. Medema GJ, Schets FM, van de Giessen AW, Havelaar AH. Lack of colonization of 1 day old chicks by viable, nonculturable Campylobacter jejuni. J Appl Bacteriol 1992; 72 : 512-516.

21. Kim NW, Bingham H, Khawaja $\mathrm{R}$ et al. Physical map of Campylobacter jejuni TGH9011 and localization of 10 genetic markers by use of pulsed-field gel electrophoresis. J Bacteriol 1992; 174: 3494-3498.

22. Taylor DE, Eaton M, Yan W, Chang N. Genome maps of Campylobacter jejuni and Campylobacter coli. J Bacteriol 1992; 174: 2332-2337.

23. Nuijten PJM, Bartels C, Bleumink-Pluym NMC, Gaastra W, Van der Zeijst BAM. Size and physical map of the Campylobacter jejuni chromosome. Nucleic Acids Res 1990; 18: $6211-6214$. 
24. Chang N, Taylor DE. Use of pulsed-field agarose gel electrophoresis to size genomes of Campylobacter species and to construct a Sall map of Campylobacter jejuni UA580. $J$ Bacteriol 1990; 172: 5211-5217.

25. Taylor DE. Genetics of Campylobacter and Helicobacter. Annu Rev Microbiol 1992; 46: 35-64.

26. Miller JF, Dower WJ, Tompkins LS. High-voltage electroporation of bacteria: genetic transformation of Campylobacter jejuni with plasmid DNA. Proc Natl Acad Sci USA 1988; 85: 856-860.

27. Wang Y, Taylor DE. Natural transformation in Campylobacter species. J Bacteriol 1990; 172: 949-955.

28. Fyfe JAM, Davies JK. Nucleotide sequence and expression in Escherichia coli of the recA gene of Neisseria gonorrhoeae. Gene 1990; 93: 151-156.

29. Seifert HS, Ajioka RS, Marchal C, Sparling PF, So M. DNA transformation leads to pilin antigenic variation in Neisseria gonorrhoeae. Nature 1988; 336: 392-395.

30. Goodman HJK, Woods DR. Molecular analysis of the Bacteriodes fragilis recA gene. Gene 1990; 94: 77-82.

31. Ramesar RS, Abratt V, Woods DR, Rawlings DE. Nucleotide sequence and expression of a cloned Thiobacillus ferrooxidans recA gene in Escherichia coli. Gene 1989; 78: $1-8$.

32. Wang WB, Tessman ES. Location of functional regions of the Escherichia coli RecA protein by DNA sequence analysis of RecA protease-constitutive mutants. $J$ Bacteriol 1986 168: 901-910.

33. Kiernan M, Wren BW, Ketley JM. Identification of the Campylobacter jejuni recA gene using a PCR-based strategy. Acta Gastro-Enterol Belg 1993; 56: 17.

34. Guerry P, Pope PM, Burr DH, Leifer J, Joseph SW, Bourgeois AL. Development and characterization of $\operatorname{rec} A$ mutants of Campylobacter jejuni for inclusion in attenuated vaccines. Infect Immun 1994; 62: 426-432.

35. Manoil C, Beckwith J. TnphoA : a transposon probe for protein export signals. Proc Natl Acad Sci USA 1985; 82 8129-8133.

36. Labigne-Roussel A, Harel J, Tompkins L. Gene transfer from Escherichia coli to Campylobacter species: development of shuttle vectors for genetic analysis of Campylobacter jejuni. $J$ Bacteriol 1987; 169: 5320-5323.

37. Butzler JP, Skirrow MB. Campylobacter enteritis. Clinics Gastroent $1979 ; 8$ : 737-765.

38. Walker RI, Caldwell MB, Lee EC, Guerry P, Trust TJ, RuizPalacios GM. Pathophysiology of Campylobacter enteritis. Microbiol Rev 1986; 50: 81-94.

39. Skirrow MB, Blaser MJ. Clinical and epidemiologic considerations. In: Nachamkin I, Blaser MJ, Tompkins LS (eds) Campylobacter jejuni: current status and future trends. Washington DC, American Society for Microbiology. 1992: 3-8.

40. Rhodes KM, Tattersfield AE. Guillain-Barré syndrome associated with Campylobacter infection. BMJ 1982; 285: 173-174.

41. Kuroki S, Haruta T, Yoshioka M, Kobayashi Y, Nukina M, Nakanishi H. Guillain-Barré syndrome associated with Campylobacter infection. Pediatr Infect Dis J 1991; 10: 149-51.

42. Mishu B, Blaser MJ. Role of infection due to Campylobacter jejuni in the initiation of Guillain-Barré syndrome. Clin Infect Dis 1993; 17: 104-108.

43. Fujimoto S, Yuki N, Itoh T, Amako K. Specific serotype of Campylobacter jejuni associated with Guillain-Barré syndrome. J Infect Dis 1992; 165: 183.

44. Kuroki S, Saida T, Nukina M et al. Campylobacter jejuni strains from patients with Guillain-Barré syndrome belong mostly to Penner serogroup 19 and contain beta- $N$-acetylglucosamine residues. Ann Neurol 1993; 3: 243-247.

45. Skirrow MB. A demographic survey of Campylobacter, Salmonella and Shigella infections in England. A Public Health Laboratory Service survey, Epidemiol Infect 1987; 99: 647-657.

46. Kendall EJC, Tanner EI. Campylobacter enteritis in general practice. J Hyg 1982; 88: 155-163.

47. Sockett PN, Pearson AD. Cost implications of human Campylobacter infections. In: Kaijser B, Falsen E (eds) Campylobacter IV. Göteburg, Sweden, University of Göteburg. 1988: 261-264.

48. Taylor DN. Campylobacter jejuni infections in developing countries. In: Nachamkin I, Blaser MJ, Tompkins LS (eds) Campylobacter jejuni: current status and future trends. Washington DC, American Society for Microbiology. 1992: 20-30.

49. Everest PH, Goossens H, Butzler J-P et al. Differentiated Caco2 cells as a model for enteric invasion by Campylobacter jejuni and C. coli. J Med Microbiol 1992; 37: 319-325.

50. Ruiz-Palacios GM, Torres J, Torres NI, Escamilla E, RuizPalacios BR, Tamayo J. Cholera-like enterotoxin produced by Campylobacter jejuni. Lancet $1983: 250-253$.

51. Ruiz-Palacios GM, López-Vidal Y, Torres J, Torres N. Serum antibodies to heat-labile enterotoxin of Campylobacter jejuni. J Infect Dis 1985; 152: 413-416.

52. Ruiz-Palacios GM, Cervantes LE, Newburg DS, Lopez-Vidal Y, Calva JJ. In vitro models for studying Campylobacter infections. In: Nachamkin I, Blaser MJ, Tompkins LS (eds) Campylobacter jejuni: current status and future trends. Washington DC, American Society for Microbiology. 1992: 176-183.

53. Skirrow MB. Campylobacter. Lancet $1990 ; 336$ : 921-923.

54. Stern NJ. Reservoirs for $C$. jejuni and approaches for intervention in poultry. In: Nachamkin I, Blaser MJ, Tompkins LS (eds) Campylobacter jejuni: current status and future trends. Washington, DC, American Society for Microbiology. 1992: 49-60.

55. Southern JP, Smith RMM, Palmer SR. Bird attack on milk bottles: possible mode of transmission of Campylobacter jejuni to man. Lancet 1990; 336: 1425-1427.

56. Robinson DA. Infective dose of Campylobacter jejuni in milk. BMJ 1981; 282: 1584 .

57. Black RE, Levine MM, Clements ML, Hughes TP, Blaser MJ. Experimental Campylobacter jejuni infection in humans. $J$ Infect Dis 1988; 157: 472-479.

58. Morooka T, Umeda A, Amako K. Motility as an intestinal colonization factor for Campylobacter jejuni. J Gen Microbiol 1985; 131: 1973-1980.

59. Newell DG, McBride H, Dolby JM. Investigations on the role of flagella in the colonization of infant mice with Campylobacter jejuni and attachment of Campylobacter jejuni to human epithelial cell lines. $J$ Hyg 1985; 95: 217-227.

60. Caldwell MB, Guerry P, Lee EC, Burans JP, Walker RI. Reversible expression of flagella in Campylobacter jejuni. Infect Immun 1985; 50: 941-943.

61. Aguero-Rosenfeld ME, Yang X-H, Nachamkin I. Infection of adult Syrian hamsters with flagellar variants of Campylobacter jejuni. Infect Immun 1990; 58: 2214-2219.

62. McSweegan E, Walker RI. Identification and characterization of two Campylobacter jejuni adhesins for cellular and mucous substrates. Infect Immun 1986; 53: 141-148.

63. Wenman WM, Chain J, Louie TJ et al. Antigenic analysis of Campylobacter flagellar protein and other proteins. J Clin Microbiol 1985; 21: 108-112.

64. Harris LA, Logan SM, Guerry P, Trust TJ. Antigenic variation of Campylobacter flagella. $J$ Bacteriol 1987; 169: 5066-5071.

65. Nuijten PJM, Wassenaar TM, Newell DG, Van Der Zeijst BAM. Molecular characterization and analysis of Campylobacter jejuni flagellin genes and proteins. In: Nachamkin I, Blaser MJ, Tompkins LS (eds) Campylobacter jejuni: current status and future trends. Washington DC, American Society for Microbiology. 1992: 282-96.

66. Guerry P, Alm RA, Power ME, Trust TJ. Molecular and structural analysis of Campylobacter flagellin. In: Nachamkin I, Blaser MJ, Tompkins LS (eds) Campylobacter jejuni: current status and future trends. Washington DC, American Society for Microbiology. 1992: 267-281.

67. Grant CCR, Konkel ME, Cieplak W, Tompkins LS. Role of flagella in adherence, internalization, and translocation of Campylobacter jejuni in nonpolarized and polarized epithelial cell cultures. Infect Immun 1993; 61: 1764-1771.

68. Wassenaar TM, Bleumink-Pluym NMC, van der Zeijst BAM. Inactivation of Campylobacter jejuni flagellin genes by homologous recombination demonstrates that $\mathrm{flaA}$ but not $f a B$ is required for invasion. $E M B O J 1991 ; 10: 2055-2061$.

69. Wassenaar TM, van der Zeijst BAM, Ayling R, Newell DG. Colonization of chicks by motility mutants of Campylobacter jejuni demonstrates the importance of 
flagellin A expression. J Gen Microbiol 1993; 139: 1171-1175.

70. Nachamkin I, Yang X-H, Stern NJ. Role of Campylobacter jejuni flagella as colonization factors for three-day-old chicks: analysis with flagellar mutants. Appl Environ Microbiol 1993; 59: 1269-1273.

71. Ferrero RL, Lee A. Motility of Campylobacter jejuni in a viscous environment: comparison with conventional rod shaped bacteria. J Gen Microbiol 1988; 134: 53-59.

72. Lee A, O'Rourke JL, Barrington PJ, Trust TJ. Mucous colonization as a determinant of pathogenicity in intestinal infection by Campylobacter jejuni: a mouse cecal model. Infect Immun 1986; 51: 536-546.

73. deMelo MA, Pechère J-C. Identification of Campylobacter jejuni surface proteins that bind to eucaryotic cells in vitro. Infect Immun 1990; 58: 1749-1756.

74. Fauchere J-L, Kervella M, Pages JM, Fendri C. In vitro study of virulence factors of enteric Campylobacter spp. In: Nachamkin I, Blaser MJ, Tompkins LS (eds) Campylobacter jejuni: current status and future trends. Washington DC, American Society for Microbiology. 1992: 168-175.

75. Kervella M, Pagès J-M, Pei Z, Grollier G, Blaser MJ, Fauchère J-L. Isolation and characterization of two Campylobacter glycine-extracted proteins that bind to $\mathrm{HeLa}$ cell membranes. Infect Immun 1993; 61 : 3440-3448.

76. Pei Z, Blaser MJ. PEB1, the major cell-binding factor of Campylobacter jejuni, is a homolog of the binding component in gram-negative nutrient transport systems. $J$ Biol Chem 1993; 268 : 18717-18725.

77. Russell RG, O'Donnoghue M, Blake DC, Zulty J, DeTolla LJ Early colonic damage and invasion of Campylobacter jejuni in experimentally challenged infant Macaca mulatta. $J$ Infect Dis 1993; 168: 210-215.

78. Van Spreeuwel JP, Duursma GC, Meijer CJLM, Bax R, Rosekrans PCM, Lindeman J. Campylobacter colitis: histological, immunohistochemical and ultrastructural findings. Gut 1985; 26: 945-951.

79. Babakhani FK, Joens LA. Primary swine intestinal cells as a model for studying Campylobacter jejuni invasiveness. Infect Immun 1993; 61: 2723-2726.

80. Fauchere JL, Rosenau A, Veron M, Moyen EN, Richard S, Pfister A. Association with HeLa cells of Campylobacter jejuni and Campylobacter coli isolated from human feces. Infect Immun 1986; 54: 283-287.

81. Konkel ME, Joens LA. Adhesion to and invasion of HEp-2 Cells by Campylobacter spp. Infect Immun 1989; 57: 2984-2990.

82. deMelo MA, Gabbiani G, Pèchere J-C. Cellular events and intracellular survival of Campylobacter jejuni during infection of HEp-2 Cells. Infect Immun 1989; 57: 2214-2222.

83. Oelschlaeger TA, Guerry P, Kopecko DJ. Unusual microtubule-dependent endocytosis mechanisms triggered by Campylobacter jejuni and Citrobacter freundii. Proc Natl Acad Sci USA 1993; 90: 6884-6888.

84. Konkel ME, Cieplak W. Altered synthetic response of Campylobacter jejuni to cocultivation with human epithelial cells is associated with enhanced internalization. Infect Immun 1992; 60: 4945-4949.

85. Panigrahi P, Losonsky G, DeTolla LJ, Morris JG. Human immune response to Campylobacter jejuni proteins expressed in vivo. Infect Immun 1992; 60: 4938-4944.

86. Konkel ME, Hayes SF, Joens LA, Cieplak W. Characteristics of the internalization and intracellular survival of Campylobacter jejuni in human epithelial cell cultures. Microb Pathog 1992; 13: 357-370.

87. Russell RG, Blake DC. Cell association and invasion of Caco2 cells by Campylobacter jejuni. Infect Immun 1994; 62: 3773-3779.

88. Konkel ME, Mead DJ, Hayes SF, Cieplak W. Translocation of Campylobacter jejuni across human polarized epithelial cell monolayer cultures. J Infect Dis 1992; 166: 308-315.

89. Finlay BB, Gumbiner B, Falkow S. Penetration of Salmonella through a polarized Madin-Darby canine kidney epithelial cell monolayer. J Cell Biol 1988; 107: 221-230.

90. Finlay BB, Falkow S. Salmonella interactions with polarized human intestinal Caco-2 epithelial cells. J Infect Dis 1990; 162: 1096-1106

91. Sansonetti PJ, Arondel J, Fontaine A, d'Hauteville H, Bernardini ML. OmpB (osmo-regulation) and ics A (cell-to- cell spread) mutants of Shigella flexneri: vaccine candidates and probes to study the pathogenesis of shigellosis. Vaccine $1991 ; 9: 416-422$.

92. Hale TL. Genetic basis of virulence in Shigella species. Microbiol Rev 1991; 55: 206-224.

93. Walker RI, Rollins DM, Burr DH. Studies of Campylobacter infection in the adult rabbit. In: Nachamkin I, Blaser MJ, Tompkins LS (eds) Campylobacter jejuni: current status and future trends. Washington DC, American Society for Microbiology. 1992: 139-147.

94. Walker RI, Schmauder-Chock EA, Parker JL, Burr D. Selective association and transport of Campylobacter jejuni through $\mathrm{M}$ cells of rabbit Peyer's patches. Can J Microbiol 1988; 34: 1142-1147.

95. Kiehlbauch JA, Albach RA, Baum LL, Chang K-P. Phagocytosis of Campylobacter jejuni and its intracellular survival in mononuclear phagocytes. Infect Immun 1985; 48: 446-451.

96. Everest PH, Goossens H, Sibbons $\mathrm{P}$ et al. Pathological changes in the rabbit ileal loop model caused by Campylobacter jejuni from human colitis. J Med Microbiol 1993; 38: 316-321.

97. Blaser MJ, Smith P.F, Kohler PF. Susceptibility of Campylobacter isolates to the bacteriocidal activity of human serum. $J$ Infect Dis 1985; 151 : 227-235.

98. Johnson K, Charles I, Dougan G et al. The role of a stressresponse protein in Salmonella typhimurium virulence. Mol Microbiol 1991; 5: 401-407.

99. Lipinska B, Fayet O, Baird L, Georgopoulos C. Identification, characterization, and mapping of the Escherichia coli htrA gene, whose product is essential for bacterial growth only at elevated temperatures. J Bacteriol $1989 ; 171$ : $1574-1584$.

100. Roop RM, Fletcher TW, Sriranganathan NM, Boyle SM, Schurig GG. Identification of an immunoreactive Brucella abortus HtrA stress response protein homolog. Infect Immun 1994; 62: 1000-1007.

101. Kleanthous H. Molecular studies on the pathogenicity of Helicobacter pylori (Dissertation). University of London, London, 1994.

102. Wren BW, Colby SM, Cubberley RR, Pallen MJ. Degenerate PCR primers for the amplification of fragments from genes encoding response regulators from a range of pathogenic bacteria. FEMS Microbiol Lett 1992; 99: 287-292.

103. Wren BW, Henderson J, Ketley JM. A PCR-based strategy for the rapid construction of defined bacterial mutants. Biotechniques 1994; 16: 7-8.

104. Russell RG. Campylobacter jejuni colitis and immunity in primates: epidemiology of natural infection. In: Nachamkin I, Blaser MJ, Tompkins LS (eds) Campylobacter jejuni: current status and future trends. Washington DC, American Society for Microbiology. 1992: 148-157.

105. Fox JG. In vivo models of enteric Campylobacteriosis: natural and experimental infections. In: Nachamkin I, Blaser MJ, Tompkins LS (eds) Campylobacter jejuni: current status and future trends. Washington DC, American Society for Microbiology. 1992: 131-138.

106. Everest PH, Cole AT, Hawkey CJ et al. Roles of leukotriene $\mathbf{B}_{4}$, prostaglandin $\mathrm{E}_{2}$, and cyclic AMP in Campylobacter jejuni-induced intestinal fluid secretion. Infect Immun $1993 ; 61$ : $4885-4887$.

107. Perez-Perez GI, Taylor DN, Echeverria PD, Blaser MJ. Lack of evidence of enterotoxin involvement in pathogenesis of Campylobacter diarrhea. In: Nachamkin I, Blaser MJ, Tompkins LS (eds) Campylobacter jejuni: current status and future trends. Washington DC, American Society for Microbiology. 1992: 184-192.

108. Moore MA, Blaser MJ, Perez-Perez GI, O'Brien AD. Production of a Shiga-like cytotoxin by Campylobacter. Microb Pathog 1988; 4: 455-462.

109. Johnson WM, Lior H. Toxins produced by Campylobacter jejuni and Campylobacter coli. Lancet 1984; 1 : 229-230.

110. Guerrant RL, Wanke CA, Pennie RA, Barrett LJ, Lima AAM, O'Brien AD. Production of a unique cytotoxin by Campylobacter jejuni. Infect Immun 1987; 55: 2526-2530.

111. Mahajan S, Rodgers FG. Isolation, characterization, and host-cell-binding properties of a cytotoxin from Campylobacter jejuni. J Clin Microbiol 1990; 28: $1314-1320$. 
112. Kita E, Oku D, Hamuro A et al. Hepatotoxic activity of Campylobacter jejuni. J Med Microbiol 1990; 33: 171-182.

113. Cover TL, Perez-Perez GI, Blaser MJ. Evaluation of cytotoxic activity in fecal filtrates from patients with Campylobacter jejuni or Campylobacter coli enteritis. FEMS Microbiol Lett 1990; 70: 301-304.

114. Pickett CL, Auffenberg T, Pesci EC, Sheen VL, Jusuf SSD. Iron acquisition and hemolysin production by Campylobacter jejuni. Infect Immun 1992; 60: 3872-3877.

115. Johnson WM, Lior H. A new heat-labile cytolethal distending toxin (CLDT) produced by Campylobacter spp. Microb Pathog 1988; 4: 115-126.

116. Daikoku T, Suzuki S, Oka S, Takama K. Profiles of enterotoxin and cytotoxin production in Campylobacter jejuni and C. coli. FEMS Microbiol Lett 1989; 58: 33-36.

117. Guerrant RL, Fang G, Pennie RA, Pearson RD. In vitro models for studying Campylobacter jejuni infections. In: Nachamkin I, Blaser MJ, Tompkins LS (eds) Campylobacter jejuni: current status and future trends. Washington DC, American Society for Microbiology. 1992: 160-167.

118. Bag PK, Ramamurthy T, Nair UB. Evidence for the presence of a receptor for the cytolethal distending toxin (CLDT) of Campylobacter jejuni on $\mathrm{CHO}$ and $\mathrm{HeLa}$ cell membranes and development of a receptor-based enzymelinked immunosorbent assay for detection of CLDT. FEMS Microbiol Lett 1993; 114: 285-292.

119. McCardell BA, Madden JM, Stanfield JT. Effect of iron concentration on toxin production in Campylobacter jejuni and Campylobacter coli. Can J Microbiol 1986; 32 395-401.

120. Klipstein FA, Engert RF. Properties of crude Campylobacter jejuni heat-labile enterotoxin. Infect Immun 1984; 45 $314-319$.

121. Saha SK, Sanyal SC. Production and characterisation of Campylobacter jejuni enterotoxin in a synthetic medium and its assay in rat ileal loops. FEMS Microbiol Lett 1990 67: 333-338.

122. McCardell BA, Madden JM, Lee EC. Production of choleralike toxin by Campylobacter jejuni/coli. Lancet $1984 ; 1$ : 448-449.

123. Klipstein FA, Engert RF. Immunological relationship of the B subunits of Campylobacter jejuni and Escherichia coli heat-labile enterotoxins. Infect Immun 1985; 48: 629-633.

124. McCardell BA, Madden JM, Lee EC. Campylobacter jejun and Campylobacter coli production of a cytotonic toxin immunologically similar to cholera toxin. J Food Protection 1984; 47: 943-949.

125. Goossens H, Butzler JP, Takeda Y. Demonstration of choleralike enterotoxin production by Campylobacter jejuni. FEMS Microbiol Lett 1985; 29: 73-76.

126. Bag PK, Ramamurthy T, Takeda Y, Pal SC, Nair GB. Identification of subunits of cholera toxin in stool specimens of patients with campylobacteriosis by Western immunoblotting. Biomed Lett 1992; 47: 375-382.

127. Suzuki S, Kawaguchi M, Mizuno K, Takama K, Yuki N. Immunological properties and ganglioside recognitions by Campylobacter jejuni-enterotoxin and cholera toxin. FEMS Immunol Med Microbiol 1994; 8: 207-212.

128. Baig BH, Wachsmuth IK, Morris GK, Hill WE. Probing of Campylobacter jejuni with DNA coding for Escherichia coli heat-labile enterotoxin. J Infect Dis 1986; 154: 542.

129. Calva E, Torres J, Vazquez M, Angeles V, de la Vega H, RuizPalacios GM. Campylobacter jejuni chromosoma sequences that hybridize to Vibrio cholerae and Escherichia coli LT enterotoxin genes. Gene 1989; 75 : 243-251.

130. Mathan VI, Rajan DP, Klipstein FA, Engert RF Enterotoxigenic Campylobacter jejuni among children in South India. Lancet 1984: 981.

131. Konkel ME, Lobet Y, Cieplak W. Examination of multiple isolates of Campylobacter jejuni for evidence of cholera toxin-like activity. In: Nachamkin I, Blaser $\mathbf{M J}$, Tompkins LS (eds) Campylobacter jejuni: current status and future trends. Washington DC, American Society for Microbiology. 1992: 193-198.

132. Perez-Perez GI, Cohn DL, Guerrant RL, Patton CM, Reller LB, Blaser MJ. Clinical and immunologic significance of cholera-like toxin and cytotoxin production by Campylobacter species in patients with acute inflam- matory diarrhea in the USA. $J$ Infect Dis 1989; 160 $460-468$.

133. Demarco de Hormaeche $R$, Macpherson $A$, Bowe $F$ Hormaeche CE. Alterations of the LPS determine virulence of Neisseria gonorrhoeae in guinea-pig subcutaneous chambers. Microb Pathog 1991; 11: 159-170.

134. Moxon RE, Maskell D. Haemophilus influenzae lipopolysaccharide: The biochemistry and biology of a virulence factor. In: Hormaeche CE, Penn CW, Smyth CJ (eds) Molecular biology of bacterial infection: current status and future perspectives, vol 49. Cambridge, Cambridge University Press. 1992: 75-96.

135. Mills SD, Aspinall GO, McDonald AG, Raju TS, Kurjanczyk LA, Penner JL. Lipopolysaccharide antigens of Campylobacter jejuni. In: Nachamkin I, Blaser MJ, Tompkins LS (eds) Campylobacter jejuni: current status and future trends. Washington DC, American Society for Microbiology. 1992: 223-229.

136. Aspinall GO, McDonald AG, Pang H. Structures of the O chains from lipopolysaccharides of Campylobacter jejuni serotypes O:23 and O:36. Carbohydr Res 1992; 231: 13-30.

137. Aspinall GO, McDonald AG, Raju TS, Pang H, Moran AP Penner JL. Chemical structures of the core regions of Campylobacter jejuni serotypes $\mathrm{O}: 1, \mathrm{O}: 4, \mathrm{O}: 23$, and O:36 lipopolysaccharides. Eur $J$ Biochem 1993; 213 1017-1027.

138. Aspinall GO, McDonald AG, Raju TS et al. Chemical structure of the core region of Campylobacter jejuni serotype O:2 lipopolysaccharide. Eur J Biochem 1993; 213: 1029-1037.

139. Aspinall GO, McDonald AG, Raju TS et al. Serological diversity and chemical structures of Campylobacter jejuni low-molecular-weight lipopolysaccharides. J Bacteriol 1992; 174: 1324-1332.

140. Conrad RS, Galanos C. Characterization of Campylobacter jejuni lipopolysaccharide. Curr Microbiol 1990; 21 : 377-379.

141. Aspinall GO, McDonald AG, Pang H, Kurjanczyk LA, Penner JL. Lipopolysaccharide of Campylobacter coli serotype $\mathrm{O}: 30$. Fractionation and structure of liberated core oligosaccharide. J Biol Chem 1993; 268: 6263-6268.

142. Moran AP, Rietschel ET, Kosunen TU, Zähringer U. Chemical characterization of Campylobacter jejuni lipopolysaccharides containing $\mathrm{N}$-acetylneuraminic acid and 2,3-diamino-2,3-dideoxy-D-glucose. J Bacteriol 1991 ; 173: 618-626.

143. Calderwood S, Knapp S, Peterson K, Taylor R, Mekalanos JJ. Coordinate regulation of virulence determinants. In: Fehrenbach FJ et al. (eds) Bacterial protein toxins. Gustav Fischer, Stuttgart, Zentralbl Bakteriol Suppl. 1988; 17 169-175.

144. Bagg A, Neilands JB. Molecular mechanism of regulation of siderophore-mediated iron assimilation. Microbiol Rev 1987; 51 : 509-518.

145. Bjorn MJ, Iglewski BH, Ives SK, Sadoff JC, Vasil ML. Effect of iron on yields of exotoxin A in cultures of Pseudomonas aeruginosa PA-103. Infect Immun 1978; 19: 785-791.

146. Bjorn MJ, Sokol PA, Iglewski BH. Influence of iron on yields of extracellular products in Pseudomonas aeruginosa cultures. J Bacteriol 1979; 138: 193-200.

147. Calderwood SB, Mekalanos JJ. Iron regulation of shiga-like toxin expression in Escherichia coli is mediated by the fur locus. $J$ Bacteriol 1987; 169: 4759-4764.

148. Dubos RJ, Geiger JW. Preparation and properties of Shiga toxin and toxoid. $J$ Exp Med 1946; 84: 143-156.

149. Pappenheimer AM. The pathogenesis of diphtheria. Symposium of the Society for General Microbiology $1955 ; 5$ : 40-56.

150. Calderwood SB, Mekalanos JJ. Confirmation of the Fur operator site by insertion of a synthetic oligonucleotide into an operon fusion plasmid. $J$ Bacteriol $1988 ; 170$ 1015-1017.

151. Hantke K. Regulation of ferric iron transport in Escherichia coli $\mathrm{K} 12$ : isolation of a constitutive mutant. $M G G 1981$ 182: 288-292.

152. Litwin CM, Boyko SA, Calderwood SB. Cloning, sequencing, and transcriptional regulation of the Vibrio cholerae fur gene. J Bacteriol 1992; 174: 1897-1903.

153. Litwin CM, Calderwood SB. Cloning and genetic analysis of 
the Vibrio vulnificus fur gene and construction of a fur mutant by in vivo marker exchange. $J$ Bacteriol $1993 ; 175$ : 706-715.

154. Waldbeser LS, Tolmasky ME, Actis LA, Crosa JH. Mechanisms for negative regulation by iron of the fat A outer membrane protein gene expression in Vibrio anguillarum 775. J Biol Chem 1993; 268: 10433-10439.

155. Staggs TM, Perry RD. Identification and cloning for a fur regulatory gene in Yersinia pestis. J Bacteriol 1991; 173: 417-425.

156. Prince RW, Cox CD, Vasil ML. Coordinate regulation of siderophore and exotoxin A production: molecular cloning and sequencing of the Pseudomonas aeruginosa fur gene. J Bacteriol 1993; 175: 2589-2598.

157. Berish SA, Subbarao S, Chen CY, Trees DL, Morse SA. Identification and cloning of a fur homolog from Neisseria gonorrhoeae. Infect Immun 1993; 61: 4599-4606.

158. Thompson SA, Wang LL, West A, Sparling PF. Neisseria meningitidis produces iron-regulated proteins related to the RTX family of exoproteins. $J$ Bacteriol $1993 ; 175$ : $811-818$.

159. Chen L, James LP, Helmann JD. Metalloregulation in Bacillus subtilis: isolation and characterization of two genes differentially repressed by metal ions. J Bacteriol 1993; 175: $5428-5437$.

160. Boyd J, Oza MN, Murphy JR. Molecular cloning and DNA sequence analysis of a diphtheria tox iron-dependent regulatory element $(d t x R)$ from Corynebacterium diphtheriae. Proc Natl Acad Sci USA 1990; 87: 5968-5972.

161. Field LH, Headley VL, Payne SM, Berry LJ. Influence of iron on growth, morphology, outer membrane protein com- position, and synthesis of siderophores in Campylobacter jejuni. Infect Immun 1986; 54: 126-132.

162. Wooldridge KG, Williams $\mathrm{PH}$, Ketley JM. Iron-responsive genetic regulation in Campylobacter jejuni: cloning and characterisation of a fur homolog. J Bacteriol 1994; 176 : $5852-5856$

163. De Lorenzo V, Herrero M, Giovannini F, Neilands JB. Fur (ferric uptake regulation) protein and CAP (cataboliteactivator protein) modulate transcription of fur gene in Escherichia coli. Eur J Biochem 1988; 173: 537-546.

164. Coy M, Neilands JB. Structural dynamics and functional domains of the fur protein. Biochemistry 1991; 30: $8201-8210$

165. Deretic V, Konyecsni WM, Mohr CD, Martin DW, Hibler NS. Common denominators of promoter control in Pseudomonas and other bacteria. Bio/Technology 1989; 7: 1249-1254.

166. Stock JB, Ninfa AJ, Stock AM. Protein phosphorylation and regulation of adaptive responses in bacteria. Microbiol Rev $1989 ; 53: 450-490$.

167. Parkinson JS. Signal transduction schemes of bacteria. Cell 1993; 73: 857-871.

168. Wanner BL. Is cross regulation by phosphorylation of twocomponent response regulator proteins important in bacteria? J Bacteriol 1992; 174: 2053-2058.

169. Alm RA, Guerry P, Trust TJ. The Campylobacter sigma ${ }^{54}$ flaB flagellin promoter is subject to environmental regulation. $J$ Bacteriol 1993; 175: 4448-4455.

170. Miller S, Pesci EC, Pickett CL. A Campylobacter jejuni homolog of the LcrD/FlbF family of proteins is necessary for flagellar biogenesis. Infect Immun 1993; 61: 2930-2936.

\section{Note added in proof}

The recent publication of two papers directly relate to observations made in this article. Wassenaar et al. (Microbiology 1995; 141: 95-100) have demonstrated the exchange of flagellin gene sequences during the co-culture of appropriately marked $C$. jejuni mutants. This observation provides a possible molecular basis for antigenic or phase variability at the $f l a$ locus and supports a wider role for natural transformation in the generation of genetic diversity in the species. Yao et al. (Molecular Microbiology 1994; 14: 883-893) have shown that a mutation in a gene called pflA (paralysed flagella) results in immobilised full length flagella and a mutant strain which can adhere to but not invade enterocyte-like cells. Therefore, contrary to some previous work, flagella could have a role in adhesion as well as invasion of host cells. 